\title{
Recovery of High Purity Zinc Oxide through Dry and Wet Processes from Low-Quality Dross Containing Zinc
}

\author{
Byung-Woo Lee ${ }^{1}$, Sung-Ho Kim², Jei-Pil Wang ${ }^{2 *}$ \\ ${ }^{1}$ Department of Materials System Engineering, Pukyong National University, Busan 48513, Republic of Korea. \\ ${ }^{2}$ Department of Metallurgical Engineering, Pukyong National University, Busan 48513, Republic of Korea.
}

\begin{abstract}
In this study, nano-grade zinc oxide powder was produced through a dry/wet fusion process of zinc dross generated by a melting process using an electric furnace and collected through a dust collector. The process of recovering nano sized zinc oxide powder consists of vapor distillation to recover $\mathrm{Zn}$ by mixing cast iron soluble dust and cokes, selective leaching of $\mathrm{Zn}\left(\mathrm{NO}_{3}\right)_{2}$ through the addition of $\mathrm{HNO}_{3}$, and recovery of nano zinc oxide powder through $\mathrm{NH}_{3}$ neutralization. The vapor distillation process was maintained for 1 hour at $700^{\circ} \mathrm{C}$ with cast iron melting dust : cokes $=1: 1$ weight ratio. Thereafter, the deposited $\mathrm{Zn}$ was recovered, and the concentration of $\mathrm{Zn}$ and $30 \%$ HNO3 was maintained at room temperature in a $1: 6$ molar ratio, and then neutralized and dried by introducing a concentration of $28 \% \mathrm{NH} 3$ to recover pure $\mathrm{ZnO}$. Through the above process, finally, a purity of $99.99 \%$, an average particle size of $150 \mathrm{~nm}$, and a plate-shaped $\mathrm{ZnO}$ nano powder were prepared.
\end{abstract}

Keywords: dry distillation; acid leaching; zinc oxide; nano powder, wet process

\section{INTRODUCTION}

$\mathrm{ZnO}$ is a compound semiconductor with $3.37 \mathrm{eV}$ band gap energy, and its bond energy at room temperature is $60 \mathrm{meV}$, which is greater than thermal energy $(2626 \mathrm{meV})$, that it has established a broad market as it is used in piezoelectric body, cosmetics, and white pigment ${ }^{[1]}$; it is recently drawing attention as a high value material with great potential in optoelectronic device such as solar battery, laser, and LED, and nanostructured $\mathrm{ZnO}$ for electronic, optical, and catalytic sensor ${ }^{[2-6]}$.

However, Korea is dependent on the import of zinc mineral, which is the raw material of $\mathrm{ZnO}$, and needs to establish a stable supply system for the survival of domestic industry in the global market. For this, many studies have been conducted on ways to collect zinc from zinc scraps, but there are still many difficulties in commercializing zinc collection. In Korea, zinc is collected from electric arc furnace dust through dry processing, and a typical dry processing includes the production of metal zinc using Waelz Kiln and Plasma method ${ }^{[7,8]}$. Iron scrap is the raw material used by dry electric arc furnace steel manufacturers, and while most of it is dissolved in the refining process into products, some elements contained in the scrap such as zinc turn into dust with the supplementary materials added in electric arc furnace refining process and are discharged outside the furnace ${ }^{[9]}$. In electric arc furnace steelmaking process, about $15 \sim 25 \mathrm{~kg}$ of dust is known to be generated per 1 ton of crude steel ${ }^{[9,10]}$. Since over 100,000 ton of $\mathrm{ZnO}$ (grade 60 67\%) can be produced from over 400,000 ton of steelmaking dust ( $\mathrm{Zn}$ grade about $28 \%$ ) that is generated per year, Befesa Zinc Korea Co., Ltd. has been developing and commercializing Waelz Kiln Process-based HKZ Process since $2013^{[11]}$. Waelz method puts and reduces steelmaking dust pallets and cokes in a large capacity rotary kiln and produces $\mathrm{ZnO}$ at a high recovery rate, but contains considerably large amounts of impurities such as $\mathrm{Pb}, \mathrm{Cl}, \mathrm{Na}, \mathrm{K}$, and $\mathrm{Fe}$, and has high fuel cost. In addition, Plasma method can directly collect metal zinc that is produced through smelting reduction, but has high power consumption and low zinc purity ${ }^{[12]}$. Electrolytic method in wet process includes the use of alkaline leaching solution or acidic leaching solution [13].

Method using alkaline leaching solution uses ammonium chloride to collect high purity zinc, but zinc recovery rate is low at $50 \%{ }^{[14]}$. Also, according to study result by Havlik et al., diluted sulfuric acid was used for about $70 \sim 80 \%$ recovery rate by solid-liquid ratio condition ${ }^{[15]}$. Study by Hwang et al. reported of selective extraction of $\mathrm{Zn}$ by liquid surfactant membrane process and synthesis of high purity zinc oxide powder ${ }^{[16]}$. In addition, studies on the recovery of $\mathrm{Zn}$ and $\mathrm{ZnO}$ from low grade Zn-containing scrap are mostly about dry process such as Waelz method and Plasma method, and wet process using alkaline and acidic leaching solutions, but with low purity or recovery rate of $\mathrm{Zn}$ or $\mathrm{ZnO}$ collected, development of dry/wet fusion process may be necessary.

In this study, high purity $\mathrm{ZnO}$ was produced through dry thermal reaction and wet leaching continuous process. First, $2 \mathrm{~N}$-grade $\mathrm{Zn}$ was collected from low-grade Zn-containing scrap through dry distillation. Collected $\mathrm{Zn}$ powder was produced into high purity nano $\mathrm{ZnO}$ through acid distillation and neutralization. Produced $\mathrm{ZnO}$ was analyzed through XRD, XRF and TEM.

\section{MATERIALS}

Material used in this study is iron dross, an oxide layer that is 
produced as the uppermost part of molten metal is in contact with air while producing zinc ingot. Fig. 1 and Table 1 display the results of phase analysis and composition analysis of raw sample where phase analysis was performed by XRD (X-Ray Diffraction) and composition analysis was performed by EDS (Energy Dispersive X-ray Spectroscopy). As a result of XRD analysis, raw sample existed in the form of $\mathrm{ZnO}, \mathrm{Zn}, \mathrm{Zn}(\mathrm{OH})_{2}$, and $\mathrm{ZnS}$. As a result of composition analysis, content of $\mathrm{Zn}$ is $64.7 \%, \mathrm{O}$ is $13.41 \%, \mathrm{Na}$ is $10.7 \%, \mathrm{C}$ is $7.54 \%, \mathrm{Cl}$ is $2.32 \%, \mathrm{~S}$ is $1.10 \%, \mathrm{Al}$ is $0.33 \%, \mathrm{Si}$ is $0.13 \%$, and $\mathrm{Ca}$ is $0.1 \%$ in the raw sample.

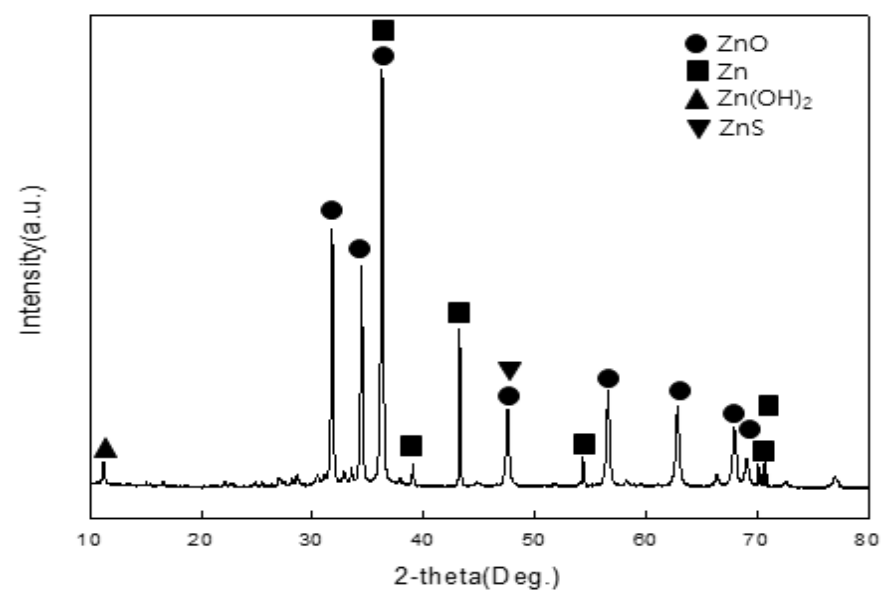

Fig. 1. XRD pattern of zinc dross

Table1. Chemical compositions of raw material

\begin{tabular}{|c|c|c|c|c|c|}
\hline Element & $\mathrm{Zn}$ & $\mathrm{O}$ & $\mathrm{Na}$ & $\mathrm{C}$ & $\mathrm{Cl}$ \\
\hline \hline wt.\% & 64.7 & 13.41 & 10.7 & 7.54 & 2.32 \\
\hline Element & $\mathrm{S}$ & $\mathrm{Al}$ & $\mathrm{Si}$ & $\mathrm{Ca}$ & \\
\hline \hline wt.\% & 1.1 & 0.33 & 0.13 & 0.1 & \\
\hline
\end{tabular}

\section{EXPERIMENT METHOD}

\subsection{Vapor Distillation}

To collect $\mathrm{Zn}$ from the raw sample selectively, zinc dross was combined with the reducing agent, cokes, and inserted into electric arc furnace. $\mathrm{Zn}$ and cokes in zinc dross were reacted for reduction reaction as well as deposition recovery of $\mathrm{Zn}$.

Vapor deposition experiment was conducted in $\mathrm{Ar}$ gas $(300 \mathrm{cc} / \mathrm{min})$ atmosphere from $30^{\circ} \mathrm{C}$ to $1100^{\circ} \mathrm{C}$ at $10^{\circ} \mathrm{C} / \mathrm{min}$ heating rate, and mix proportion of zinc dross and cokes was added at 3 conditions of 9:1, 8:2, and 7:3. Reaction time was 1 hour, 2 hours, and 3 hours.

\subsection{Acid Leaching}

$30 \% \mathrm{HNO}_{3}$ was added to leach $\mathrm{ZnO}$ selectively after collecting vapor deposited $\mathrm{Zn}$ powder, and $28 \%$ ammonia water was added for neutralization to collect nano $\mathrm{ZnO}$ powder. Reaction formulas of acid leaching and neutralization are as follows.

$\mathrm{Zn}+4 \mathrm{HNO}_{3} \rightarrow \mathrm{Zn}\left(\mathrm{NO}_{3}\right)_{2}+2 \mathrm{H}_{2} \mathrm{O}+2 \mathrm{NO}_{2} \uparrow$

$$
\mathrm{Zn}\left(\mathrm{NO}_{3}\right)_{2}+2 \mathrm{NH}_{4} \mathrm{OH} \rightarrow \mathrm{ZnO}+2 \mathrm{NH}_{4} \mathrm{NO}_{3}+\mathrm{H}_{2} \mathrm{O}
$$

Acid leaching was done under 4 conditions of $\mathrm{Zn}$ : nitric acid molar ratio $(1: 4,1: 5,1: 6,1: 7)$, and acid reaction was done under 4 conditions ( 30 minutes, 40 minutes, 50 minutes, 1 hour).

\subsection{Neutralization Reaction}

$\mathrm{ZnO}$ is an amphiprotic solution that dissolves in strong acid and strong alkali, and when ammonia water is unsaturated in neutralization, $\mathrm{ZnO}$ yield decreases as solution is acidic, and when supersaturated, $\mathrm{ZnO}$ yield decreases as solution is basic and purity deceases due to residual ammonia water. Therefore, ammonia water was experimented under 10 conditions by adding $10 \mathrm{ml}$ starting from the volume ratio of $\mathrm{ZnO}$ and ammonia water $100 \mathrm{ml}: 10 \mathrm{ml}$.

When ammonia water is added to zinc nitrate, $\mathrm{ZnO}$ powder is created, and neutralization time is when nucleation occurs. Particle size was expected to be smaller with longer neutralization time, and particle size of $\mathrm{ZnO}$ was measured under 5 conditions of 1 hour, 2 hours, 3 hours, 4 hours, and 5 hours of neutralization. To measure, SEM (Scanning Electron Microscope) analysis was performed.

\subsection{Water Leaching}

After neutralizing zinc nitrate into $\mathrm{ZnO}$, water leaching was performed to remove residual $\mathrm{NH}_{4} \mathrm{NO}_{3}$. $\mathrm{NH}_{4} \mathrm{NO}_{3}$ is easily dissolved in water and $\mathrm{ZnO}$ is not dissolved in water, and this property was used to separate them. Table 2 displays the difference in solubility of water between $\mathrm{NH}_{4} \mathrm{NO}_{3}$ and $\mathrm{ZnO}$.

Table 2. The variation in solubility of water between $\mathrm{NH}_{4} \mathrm{NO}_{3}$ and zinc oxide at elevated temperatures

\begin{tabular}{|c|c|c|}
\hline Materials & $\mathrm{NH}_{4} \mathrm{NO}_{3}$ & Zinc Oxide \\
\hline & $118 \mathrm{~g} / 100 \mathrm{ml}\left(0^{\circ} \mathrm{C}\right)$ & \\
Solubility & $150 \mathrm{~g} / 100 \mathrm{ml}\left(20^{\circ} \mathrm{C}\right)$ & Insoluble \\
in water & $297 \mathrm{~g} / 100 \mathrm{ml}\left(40^{\circ} \mathrm{C}\right)$ & \\
& $410 \mathrm{~g} / 100 \mathrm{ml}\left(60^{\circ} \mathrm{C}\right)$ & \\
\hline
\end{tabular}

For number of leaching, $\mathrm{NH}_{4} \mathrm{NO}_{3}$ and $\mathrm{ZnO}$ solution and distilled water at room temperature were experimented at 1,2, and 3 times. To measure, XRD (X-Ray Diffraction) analysis was performed.

\section{RESULT AND DISCUSSION}

\subsection{Vapor Distillation}

After vapor deposition of zinc dross, amount of zinc deposited in condenser was calculated to measure the recovery rate. Result of experiment according to the mix proportion of zinc dross and cokes is displayed in Table 3. Based on the calculation of zinc amount, process time and cokes content are proportional to recovery rate, and the optimum process time of 
International Journal of Engineering Research and Technology. ISSN 0974-3154, Volume 13, Number 7 (2020), pp. 1752-1756

(C) International Research Publication House. https://dx.doi.org/10.37624/IJERT/13.7.2020.1752-1756

3 hours and cokes content of $30 \%$ was drawn from the result of experiment.

Table 3. Recovery rate by vapor deposition process time and cokes content

\begin{tabular}{|c|c|c|c|}
\hline Cokes content & 1 & 2 & 3 \\
\hline 10 & 70.46 & 83.30 & 92.22 \\
\hline 20 & 74.23 & 86.57 & 96.83 \\
\hline 30 & 77.38 & 87.96 & 97.10 \\
\hline
\end{tabular}

XRD (X-Ray Diffraction), EDS (Energy Dispersive X-ray Spectroscopy), and XRF (X-Ray Fluorescence) analyses were performed for phase analysis and composition analysis of recovered powder, which the results are displayed in Fig. 2. Based on XRD analysis result, Zn only existed as Zn phase, and based on EDS and XRF results, zinc with over $99.3 \%$ purity was recovered.

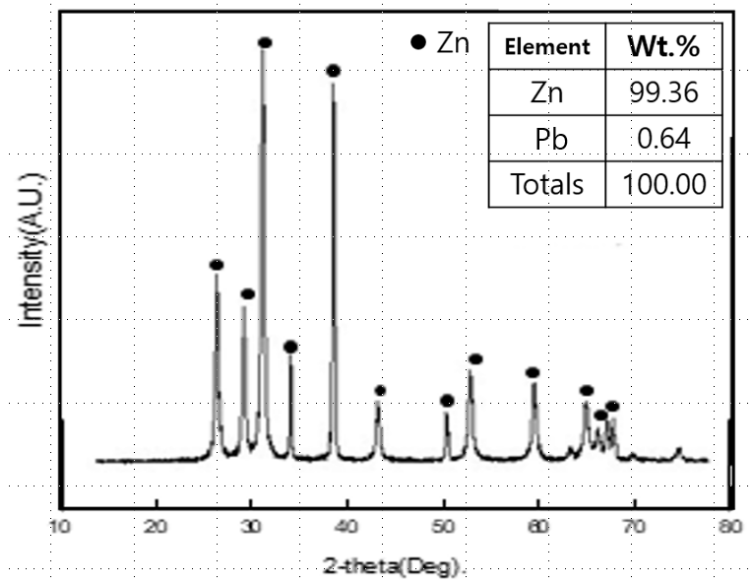

Fig. 2. Result of XRD pattern of recovered zinc

\subsection{Acid Leaching}

During the acid leaching for selective leaching of zinc nitrate, the retention period was set at 1 hour. Existence of acid leaching was confirmed through the existence of residual $\mathrm{Zn}$ after leaching the recovered $\mathrm{Zn}$ powder in nitric acid for 1 hours.

As a result, residual zinc powder was confirmed in the solution when leached at the zinc: nitric acid molar ratio of 1:4 and 1:5, but no residual zinc powder when leached at the molar ratio of $1: 6$ and 1:7, confirming complete leaching of zinc powder. Based on the result, the optimum molar ratio of 1:6 between zinc powder and nitric acid was obtained.

After obtaining the optimum zinc-nitric acid molar ratio of 1:6, an experiment was conducted to obtain the optimum acid leaching time, and existence of acid leaching was confirmed through the existence of residual zinc after the time identically set as the previous experiment.

Based on the result, residual zinc powder was confirmed at acid leaching time of 30 minutes and 40 minutes, and at 50 minutes, leaching was almost completed but residual zinc was confirmed when the outside temperature was lower than room temperature.
When acid leaching time was 1 hour, it was completely leached regardless of outside temperature, which concluded the optimum condition of acid leaching of zinc-nitric acid molar ratio at 1:6 and acid leaching time of 1 hour.

\subsection{Neutralization Reaction}

In order to compare $\mathrm{ZnO}$ recovery rate based on volume ratio of zinc nitrate and ammonia water, neutralization retention time was set at 1 hour. Recovery rate was compared by measuring the mass of powder through decompression filtration of crystals that are created when ammonia water is added. Result of $\mathrm{ZnO}$ recovery rate based on volume ratio of zinc nitrate and ammonia water is displayed in Fig. 3.

As a result, there was no recovery at the volume ratio of $100 \mathrm{ml}$ : $10 \mathrm{ml}$ and $100 \mathrm{ml}: 20 \mathrm{ml}$, and $\mathrm{ZnO}$ recovery rate increased as more ammonia water was added. However, recovery rate decreased from $100 \mathrm{ml}: 60 \mathrm{ml}$, and $\mathrm{ZnO}$ could not be recovered from 100ml: $80 \mathrm{ml}$, as it did not exist.

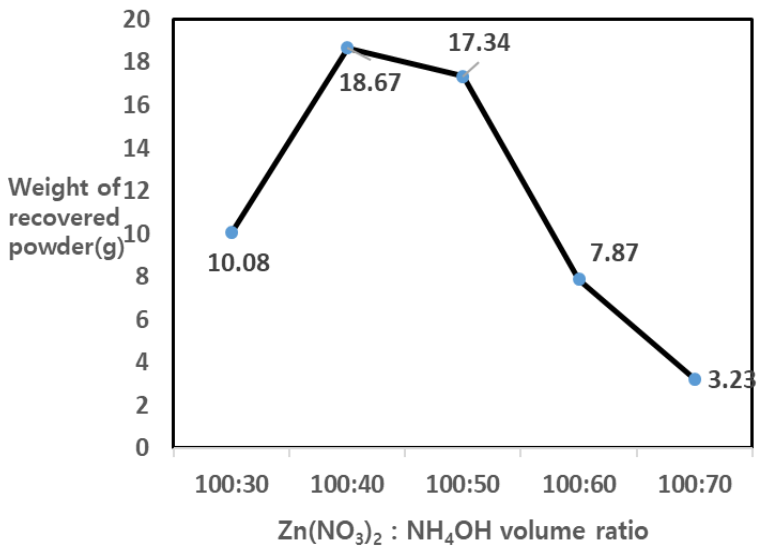

Fig. 3. Amount of recovered powder per Zinc nitrate: Ammonia water ratio

Experiment was conducted under 5 conditions by increasing by 1 hour starting from 1 hour to observe changes in particle size of $\mathrm{ZnO}$ based on neutralization time, and the result is displayed in Figure 4.

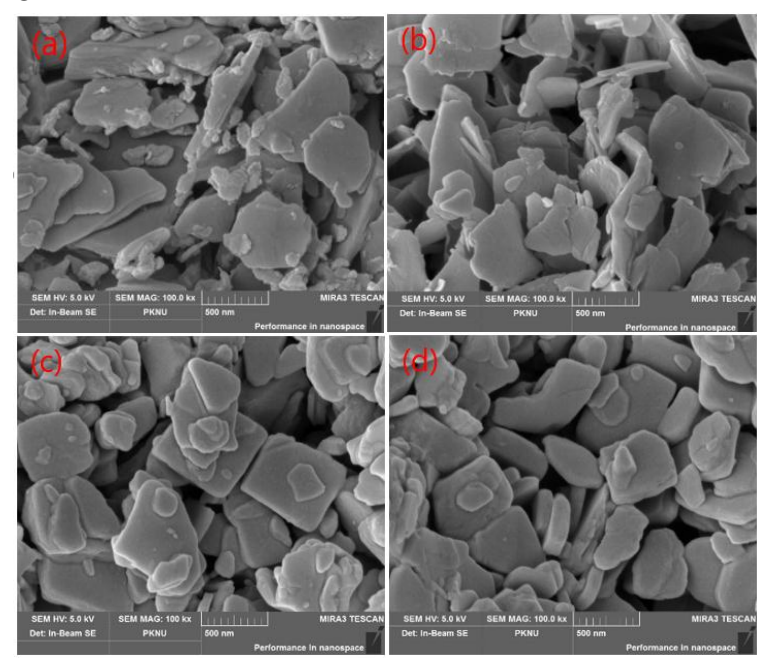

Fig. 4. Particle size of zinc oxide with reaction time: (a) $1 \mathrm{hr}$ (b) $2 \mathrm{hrs} \mathrm{(c)} 3 \mathrm{hrs} \mathrm{(d)} 4 \mathrm{hrs}$ 
As a result, particle size of $\mathrm{ZnO}$ powder was below 500nm when neutralization time was 3 hours, 4 hours, and 5 hours. However, the change in particle size was small starting from 3 hours, which concluded the optimum condition of neutralization at volume ratio between zinc nitrate and ammonia water at $100 \mathrm{mk}: 40 \mathrm{ml}$, and neutralization time of 3 hours.

\subsection{Water Leaching}

To examine the effects of number of water leaching, experiment was conducted under 3 conditions of 1,2, and 3 times at 1 hour process, and the result is displayed in Fig. 5.

When water leaching process is repeated 1 time and 2 times, $\mathrm{NH}_{4} \mathrm{NO}_{3}$ was detected in powder, but when the process was repeated 3 times, no $\mathrm{NH}_{4} \mathrm{NO}_{3}$ was detected in the recovered powder. Therefore, the optimum number of leaching is 3 times.

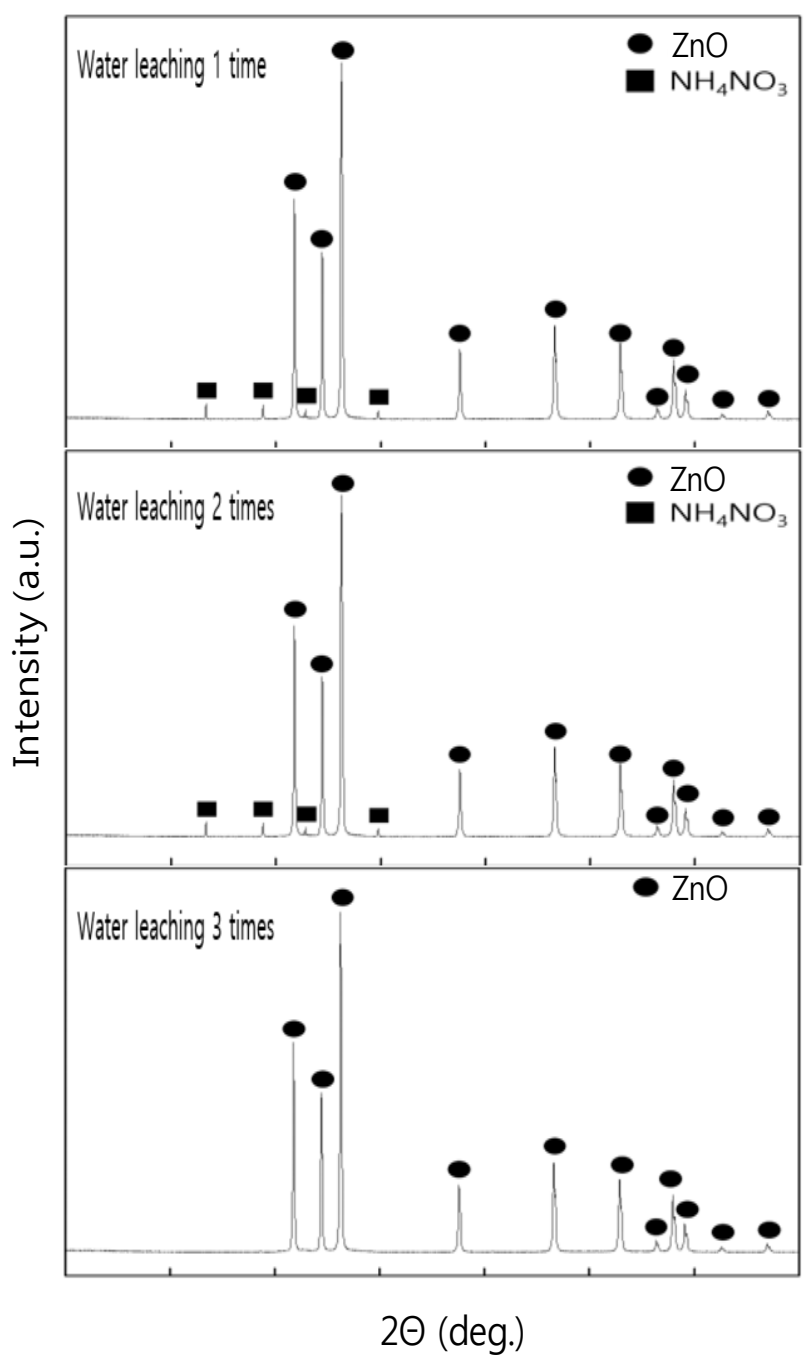

Fig. 5. XRD pattern of the number of water leaching

The final recovered $\mathrm{ZnO}$ powder was analyzed through XRF and TEM for $\mathrm{ZnO}$ purity and particle size, and the results are displayed in Table 4 and Fig. 6. Based on XRF and TEM results,
$\mathrm{ZnO}$ with over $99.9 \%$ purity and average particle size of $150 \mathrm{~nm}$ or below was recovered.

Table 4. Analysis of recovered zinc oxide examined by XRF.

unit: wt.\%

\begin{tabular}{|c|c|}
\hline Element & Content \\
\hline $\mathrm{ZnO}$ & 99.92 \\
\hline $\mathrm{NiO}$ & 0.08 \\
\hline Totals & 100 \\
\hline
\end{tabular}

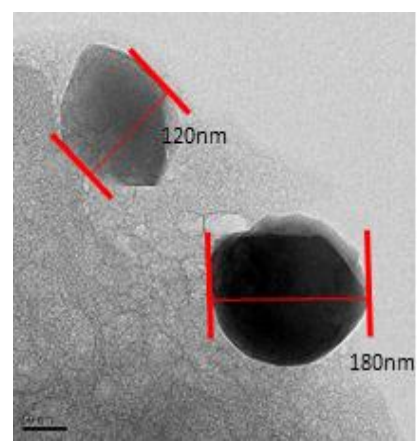

Fig. 6. TEM analysis of recovered Zinc oxide

\section{CONCLUSIONS}

This study is on the recovery of high purity nano $\mathrm{ZnO}$ powder from zinc dross through dry/wet fusion process, and aimed to obtain optimum conditions for vapor deposition, acid leaching and neutralization, and water leaching. Results of experiments are summarized as follows.

1. Optimum condition of zinc recovery through vapor deposition obtained is iron dross-cokes mix proportion of $7: 3$, reaction temperature of $1100^{\circ} \mathrm{C}$, and reaction time of 3 hours, and zinc with over $99.3 \%$ purity was recovered.

2. Optimum condition of acid leaching for recovered zinc powder was zinc-nitric acid molar ratio of 1:6 and acid leaching time of 1 hour.

3. Optimum condition of neutralization is $\mathrm{ZnO}$-ammonia water volume ratio of $100 \mathrm{ml}: 40 \mathrm{ml}$ and neutralization time of 3 hours.

4. Optimum number of water leaching to remove $\mathrm{NH}_{4} \mathrm{NO}_{3}$ to after acid leaching and neutralization is 3 times.

5. Final recovered $\mathrm{ZnO}$ powder through vapor deposition, acid leaching and neutralization, and water leaching is nano-grade high purity $\mathrm{ZnO}$ with over $99.9 \%$ purity and average particle size of $150 \mathrm{~nm}$ or below.

\section{ACKNOWLEDGEMENTS}

This work was supported by a Research Grant of Pukyong National University (2019) 


\section{REFERENCES}

[1] J. A. Park, J. H. Moon, S. J. Lee, S. C. Lim, T. Zyoung, "Fabrication and characterization of $\mathrm{ZnO}$ nanofibers by electro-spinning", Current Applied Physics. 2009;9:210-212

[2] S. Cho, J. Ma, Y. Kim, Y. Sun, G. K. L. Wong, J. B. Ketterson, "Photoluminescence and ultraviolet lasing of polycrystalline $\mathrm{ZnO}$ thin films prepared by the oxidation of the metallic Zn", Applied Physics Letters. $1999 ; 75: 2761$

[3] P. Duran, F. Capel, J. Tartaj, C. Moure, "A Strategic Two-Stage Low-Temperature Thermal Processing Leading to Fully Dense and Fine-Grained Doped-Zno Varistors", Advanced Materials. 2002; 14:137-141

[4] M. H. Huang, S. Mao, H. Feick, H. Yan, Y. Wu, H. Kind, E. Webber, R. Russo, P. Yang, "Roomtemperature ultraviolet nanowire nanolasers", Science. 2001;292:1897-1899

[5] K, Keis, E. Magnusson, H. Lindstrom, S. E Lindquist, A. Hagfeldt, "A 5\% efficient photoelectrochemical solar cell based on nanostructured $\mathrm{ZnO}$ electrodes", solar energy materials and solar cells. 2002;73:51

[6] Shalish I, Temkin H and Narayanamurti V, "Sizedependent surface luminescence in $\mathrm{ZnO}$ nanowires(4 pages)", Physical Review B, 2004;69:245-401

[7] Y. J. Liang, L. Y. Chai, H. Liu, X. B. Min, Q. Mahnood, H. J. Zhang, Y. Ke, "Hydrothermal sulfidation of zinc-containing neutralization sludge for zinc recovery and stabilization", Minerals engineering. 2012;25:14-19

[8] Tahir Sofilic, Alenka Rastovcan Mioc, Stefica Cerjan Stefanovic, Vjera Novosel Radovic, Monika Jenko, "Characterization of steel mill electric-arc furnace dust", Journal of Hazardous Materials. 2004;B109:59-70

[9] Ho-Sang Sohn, "Status of Pyrometallurgical Treatment Technology of EAF Dust", J. of Korean Inst. of Resources Recycling. 2018;27:68-76

[10] Anne-Gwénaëlle Guézennec, Jean-Christophe Huber, Fabrice Patisson, Philippe Sessiecq, Jean-Pierre Birat and Denis Ablitzer, "Dust formation in Electric Arc Furnace: Birth of the particles", Powder Technology. 2005; 157:2-11

[11] S. J. Park, I. J. Son, H. S and H. S. Son, " Leaching of Zinc from EAF Dust by Sulfuric Acid”, korean J. Met. Mater. 2015;53:793-800.

[12] D. H. Moon, S. W. Ahn, H. I. Kim, J. T. Kim, and S. W. Chang, "The Optimization of Hydrometallurgical Process for Recovery of Zinc from Electric Arc Furnace Dust(Part 1 : leaching process)", J. of Korean Inst. of Resources Recycling. 2015;24:27-33.

[13] J. M. Man, H. J. Lee, I. S. Park, K. H. Kim, S. I. Choi, "A Study of Fe Removal Efficiency of Acid Mine
Drainage by Physico-chemical Treatment", The Korean Society of Mineral and Energy Resources Engineers. 2010;47:530-538

[14] J. K. Yoo, S. H. Choi, H. S. Kim, H. K. Park, C. T. Lee, "Chlorination of Zinc sulfide with Ammonium Chloride", Applied Chemistry for Engineering, 1995;6:250-259.

[15] Havlik T, Vidor e Souza B, Bernardes AM, Schneider IA, Miskufova A, "Hydrometallurgical processing of carbon steel EAF dust", Journal of hazardous materials, 2006;135:311-318.

[16] C. H. OH, J. S. Hwang, J. W. Shim, C. T. Lee, "Selective extraction of $\mathrm{Zn}$ component from leachate of waste EAF dust using liquid membrane process", Journal of Korea Society for Waste Resources Circulation, 2000;17:619-627. 